\title{
CHARACTERIZATION OF GASEOUS AND PARTICULATE EFFLUENTS FROM THE NUCLEAR WASTE VITRIFICATION PROJECT
}
R. W. Goles
D. C. Hamilton
D. M. Robertson
F. P. Brauer
R. L. Gordon
H. G. Rieck, Jr.
J. H. Kaye

October 1979

Prepared for

the U.S. Department of Energy under Contract EY-76-C-06-1830

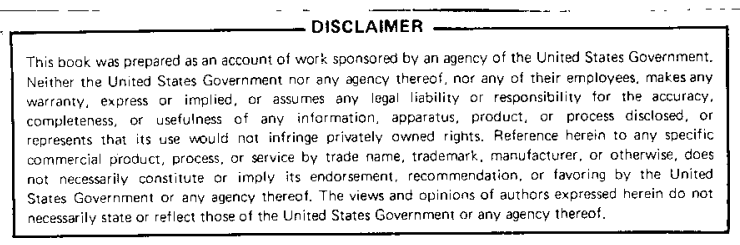

Pacific Northwest Laboratory

Richland, Washington 99352 


\section{DISCLAIMER}

This report was prepared as an account of work sponsored by an agency of the United States Government. Neither the United States Government nor any agency Thereof, nor any of their employees, makes any warranty, express or implied, or assumes any legal liability or responsibility for the accuracy, completeness, or usefulness of any information, apparatus, product, or process disclosed, or represents that its use would not infringe privately owned rights. Reference herein to any specific commercial product, process, or service by trade name, trademark, manufacturer, or otherwise does not necessarily constitute or imply its endorsement, recommendation, or favoring by the United States Government or any agency thereof. The views and opinions of authors expressed herein do not necessarily state or reflect those of the United States Government or any agency thereof. 


\section{DISCLAIMER}

Portions of this document may be illegible in electronic image products. Images are produced from the best available original document. 


\section{CONTENTS}

FIGURES $\quad \cdot \quad \cdot \quad \cdot \quad \cdot \quad \cdot \quad \cdot \quad \cdot \quad \cdot \quad \cdot \quad \cdot \quad \cdot \quad \cdot \quad \cdot$ iv

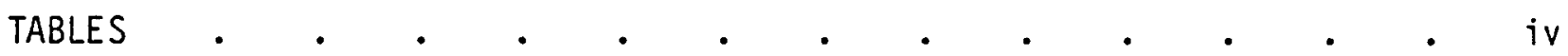

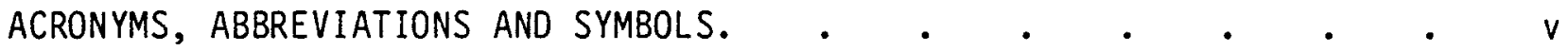

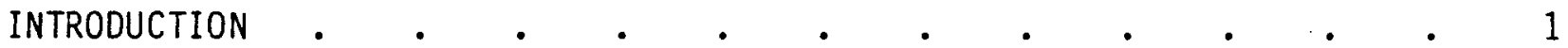

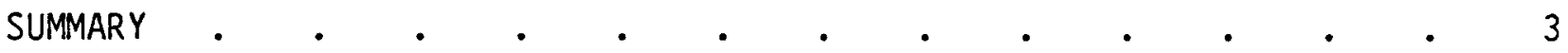
OFF-GAS SAMPLING SYSTEM.$\quad \cdot \quad \cdot \quad \cdot \quad \cdot \quad \cdot \quad \cdot \quad \cdot \quad \cdot \quad \cdot 5$

SAMPLING SITE LOCATION. $. \quad . \quad . \quad . \quad . \quad . \quad . \quad . \quad .5$

SAMPLING NETWORK • LABORATORY SAMPLE PREPARATION AND ANALYSIS.$\quad \cdot \quad \cdot \quad \cdot \quad \cdot \quad \cdot 19$ ${ }^{3} \mathrm{H}$.

${ }^{14} \mathrm{C}$ 129

NO

SEMIVOLATILES

PARTICULATES. RESULTS

$3_{H}$

${ }^{14} \mathrm{C}$

129

NO $x$

SEMI VOLATILES

PARTICULATES.

DISCUSSION

REFERENCES. 


\section{FIGURES}

$1 \quad$ Sampling Point in 324 Building B-Cell Effluent Control System . . . . . . . . . . . . 6

2 Process Line Sampling Site.

3 Detailed Schematic of the 324 Building Sampling Site

4 Detailed View of Sample Inlet

5 Differential ${ }^{3} \mathrm{H},{ }^{14} \mathrm{C}$ Sampler.

6 Caustic Scrubber Sampling System.

7 On-Line $\gamma$-Analys is System

8 Grab Sample Apparatus . . . . . . . . . . $\quad$. 17

9 SEM-Generated Photographs of $0.4 \mu \mathrm{m}$ Nuclepore Filter Sample

10 Histogram of Observed Count Frequency Versus Particle Size Interval.

$11 \quad$ Log Normal Fit to Empirical Particle Distribution

12 Semi-Empirical Particle Collection Efficiencies for a $0.4 \mu \mathrm{m}$ Nuclepore Membrane Filter

TABLES

$2 \mathrm{Ge}(\mathrm{L} i)$ Detector Specifications, Resolution and Efficiency

Tritium Emissions.

$4 \quad{ }^{14}$ C Emissions.

5 Iodine Emissions

6 Senivolatile Emissions.

7 Radionuclide Content of Particulate Matter.

8 Particulate Size Distribution Analysis. 


$\begin{array}{ll}\text { Agz } & \text { Silver-exchanged zeolite } \\ \text { AgM } & \text { Silver-exchanged mordenite } \\ \text { CMD } & \text { Curie } \\ \text { cPm } & \text { Count mean diameter } \\ \text { FWHM } & \text { Counts per minute } \\ \text { FWTM } & \text { Full width half maximum } \\ \text { HEPA } & \text { Full width tenth maximum } \\ \text { HLLW } & \text { High-efficiency particulate air (filter) } \\ \text { LWR } & \text { High-level liquid waste } \\ \ell & \text { Light water reactor } \\ m & \text { Liter } \\ \text { min } & \text { Meter } \\ \text { NO } & \text { Minute } \\ \text { NWVP } & \text { No and NO } 2 \text { only } \\ \text { POG-88 } & \text { Nuclear Waste Vitrification Project } \\ \text { PPm } & \text { Process off-gas line no. } 88, \text { used to exhaust the } \\ \text { RT } & \text { vitrification process } \\ \text { SCh } & \text { Parts per million } \\ \text { SEM } & \text { Organic tritium } \\ \text { SS } & \text { Schedule } \\ \mu & \text { Scanning electron microscope } \\ n & \text { Stainless steel } \\ \mathrm{p} & 10^{-6} \\ \mathrm{f} & 10^{-9} \\ & 10^{-12} \\ & 10^{-15} \\ \end{array}$




\section{CHARACTERIZATION OF GASEOUS AND PARTICULATE EFFLUENTS FROM THE NUCLEAR WASTE VITRIFICATION PROJECT}

\section{INTRODUCTION}

The program "Monitoring Methods for Particulate and Gaseous Effluents from Waste Solidification Processes" was initiated in FY-1977 for the purpose of developing new, reliable and accurate process monitoring techniques for future waste solidification facilities. In FY-1978, the purpose of this project was modified, limiting program objectives to that of characterizing the vitrification-related off-gas effluent associated with the Nuclear Waste Vitrification Project (NWVP). (1) All program objectives were successfully achieved and concluded in FY-1979 with the issuance of this report.

The scope of this monitoring program involved: the identification of all important effluent species likely to escape in-cell clean up devices; the construction, testing and calibration of an off-gas sampling network; and the collection, correlation and analys is of the vitrification off-gas sampling data.

This report describes the sampling and laboratory techniques employed and the off-gas analytical results obtained. 
SUMMARY

A sampling network was established to characterize the concentrations of gaseous and particulate matter generated by the vitrification of high-level liquid waste. Samples were taken during the second vitrification campaign associated with the NWVP. Subsequent laboratory sample analysis established the following total average emission levels for gaseous components in the undiluted vitrification off-gas stream: ${ }^{3} \mathrm{H}-1.2 \mu \mathrm{Ci} / \mathrm{m}^{3},{ }^{14} \mathrm{C}-0.2 \mu \mathrm{Ci} / \mathrm{m}^{3}$, ${ }^{129} \mathrm{I}-1 \mathrm{nCi} / \mathrm{m}^{3}, \mathrm{NO}_{\mathrm{x}}-0.5 \%,{ }^{99} \mathrm{TC}-1.6 \mathrm{pCi} / \mathrm{m}^{3}$, and $\gamma$-emitters $10^{5}(\mathrm{r} / \mathrm{sec}) / \mathrm{m}^{3}$.

Analysis of the particulate matter that escaped the vitrification hot cell revealed an aerosol size distribution composed almost entirely of particles exhibiting smaller diameters than the minimum value for which absolute filters are rated. The empirical geometric mean diameter of this particle size distribution was determined to be $0.13 \mu \mathrm{m}$. Moreover, the particle mass concentration present in the vitrification process off-gas stream was calculated from the distribution data to be $84.7 \mathrm{pg} / \mathrm{cm}^{3}$.

Radiologically, the particulate matter was found to be composed of ${ }^{106} \mathrm{Ru}$,

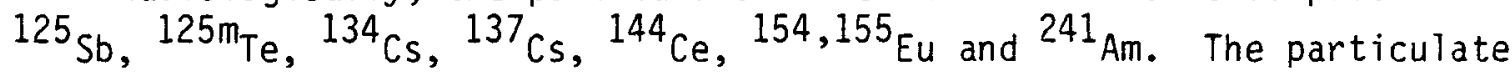
emission levels of these isotopes, in the undiluted process off-gas stream before final HEPA filtration, were determined to be: ${ }^{106} \mathrm{Ru}-44 \mathrm{nCi} / \mathrm{m}^{3}$,

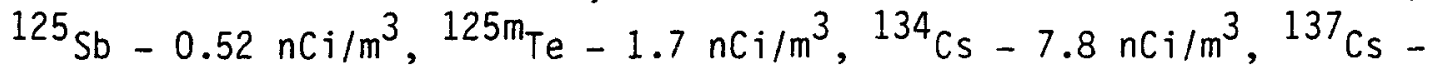
$52 \mathrm{nCi} / \mathrm{m}^{3},{ }^{144} \mathrm{Ce}-0.8 \mu \mathrm{Ci} / \mathrm{m}^{3},{ }^{154} \mathrm{Eu}-0.3 \mathrm{nCi} / \mathrm{m}^{3},{ }^{155} \mathrm{Eu}-0.18 \mathrm{nCi} / \mathrm{m}^{3}$, and ${ }^{241} \mathrm{Am}-0.19 \mathrm{nCi} / \mathrm{m}^{3}$. Particulate vitrification effluent appears to be higher in ${ }^{106} \mathrm{Ru}$ and ${ }^{125 \mathrm{~m}} \mathrm{Te}$ than would be expected from their concentrations in the HLLW feed.

A11 environmental gaseous and airborne emissions associated with the vitrification of high-level liquid waste were found to be well within PNL waste management guidelines documented in PNL-MA-8, Waste Management, Chapter 6, "Radioactive Airborne Wastes," and in ERDA Chapter 0524, "Standards for Radioactive Protection." 
OFF-GAS SAMPLING SYSTEM

The Nuclear Waste Vitrification Project was established to demonstrate that high-level liquid waste, generated from typical reprocessed LWR power reactor fuel, could be successfully solidified (vitrified) and immobilized as a borosilicate glass. A spray calciner/in-can melter system was employed to achieve this end. In this system, the concentrated HLLW solution is delivered, as an atomized spray, into a chamber heated to $750^{\circ} \mathrm{C}$, where it is concentrated, dried, and oxidized to a calcined product. The calcine, along with glassforming frits, falls into a receiving canister, which is heated to $1050^{\circ} \mathrm{C}$; there the mixture is melted and finally cooled to form the final waste glass product. This vitrification apparatus, along with the primary off-gas effluent control system, is illustrated in Figure 1.

The purpose of the program, "Monitoring Methods for Particulate and Gaseous Effluents from Waste-Solidification Processes," was to characterize concentrations of vitrification-originated effluent escaping the hot cell through the process off-gas exhaust. First a paper study was conducted to identify undesirable effluent species likely to escape all existing in-cell clean-up devices. Table 1 summarizes the findings of this study. After determination of the species to be sampled for, a sampling site was established and a monitoring network developed.

SAMPLING SITE LOCATION

A search for a suitable off-gas sampling site was conducted based on the need to obtain representative samples and the desire to locate as close to the process hot cell as physically possible. These conditions were most closely satisfied by establishing the sampling site within Room 11 of the 324 Building. In terms of the piping arrangement, the sampling point was located along the axis of the $3-i n$. process line, POG-88, at an elbow located just 6 in. from where the process line enters Room 11. In terms of the process line schematic, 


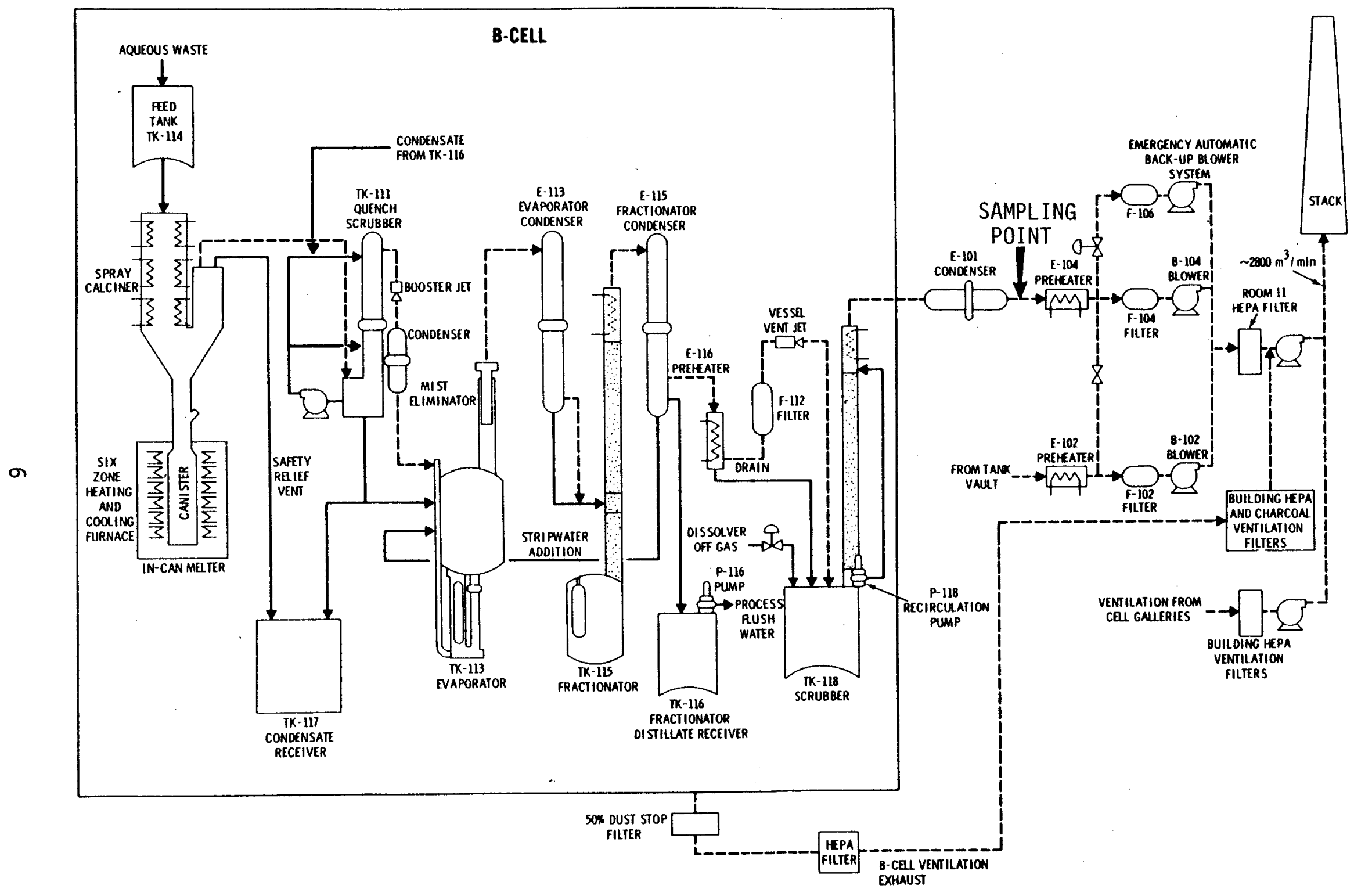

FIGURE 1. Sampling Point in 324 Building B-Cell Effluent Control System 
TABLE 1. Important Process Eff luents

$\underline{\text { Gases }}$

${ }^{3} \mathrm{H}$ as HTO, HT and organics

${ }^{14} \mathrm{C}$ as $\mathrm{CO}, \mathrm{CO}_{2}$ and organics

${ }^{129}{ }_{I}$ as $I_{2}$, HOI and organics

${ }^{N O}{ }_{x}$

Semivolatiles

${ }^{79} \mathrm{Se}$

${ }^{99} \mathrm{TC}$

${ }^{106} \mathrm{Ru}$

${ }^{125} \mathrm{Sb},{ }^{126} \mathrm{Sb}$

$125 \mathrm{~m}_{\mathrm{Te}}$

${ }^{134}$ Cs, ${ }^{135}$ Cs, ${ }^{137}$ Cs

Particulates

Fission products, including ${ }^{144} \mathrm{CePr}$

Activation products

Heavy elements

illustrated in Figure 1, this sampling site is situated between the E101 condenser and the preheater, which is designated E104. Since Room 11 is a radiation zone, most sampling equipment was deployed in Room 147, directly above Room 11, where the sampled off-gas was conveyed via a 3/4-in. heated transport tube as shown in Figure 2. For further information on the NWVP process off-gas systems the reader is referred to Reference 1 .

Sampling of the POG- 88 process line was accomplished by installing a tapered 3/4-in. Sch-40 SS pipe along the central axis of the 3-in. off-gas process line. Beyond the sample inlet, there was a large orifice ball-valve, a filter, and then a transition to a 3/4-in. SS tube. The tubing was routed to the ceiling of Room 11 and passed through a 2-in. access hole connecting Room 147 directly above. A ball valve, a five-port sampling manifold and a variable flow pumping system completed the inlet portion of the off-gas sampling line. The sampled off-gas was returned to Room 11 via a 3/4-in. SS 


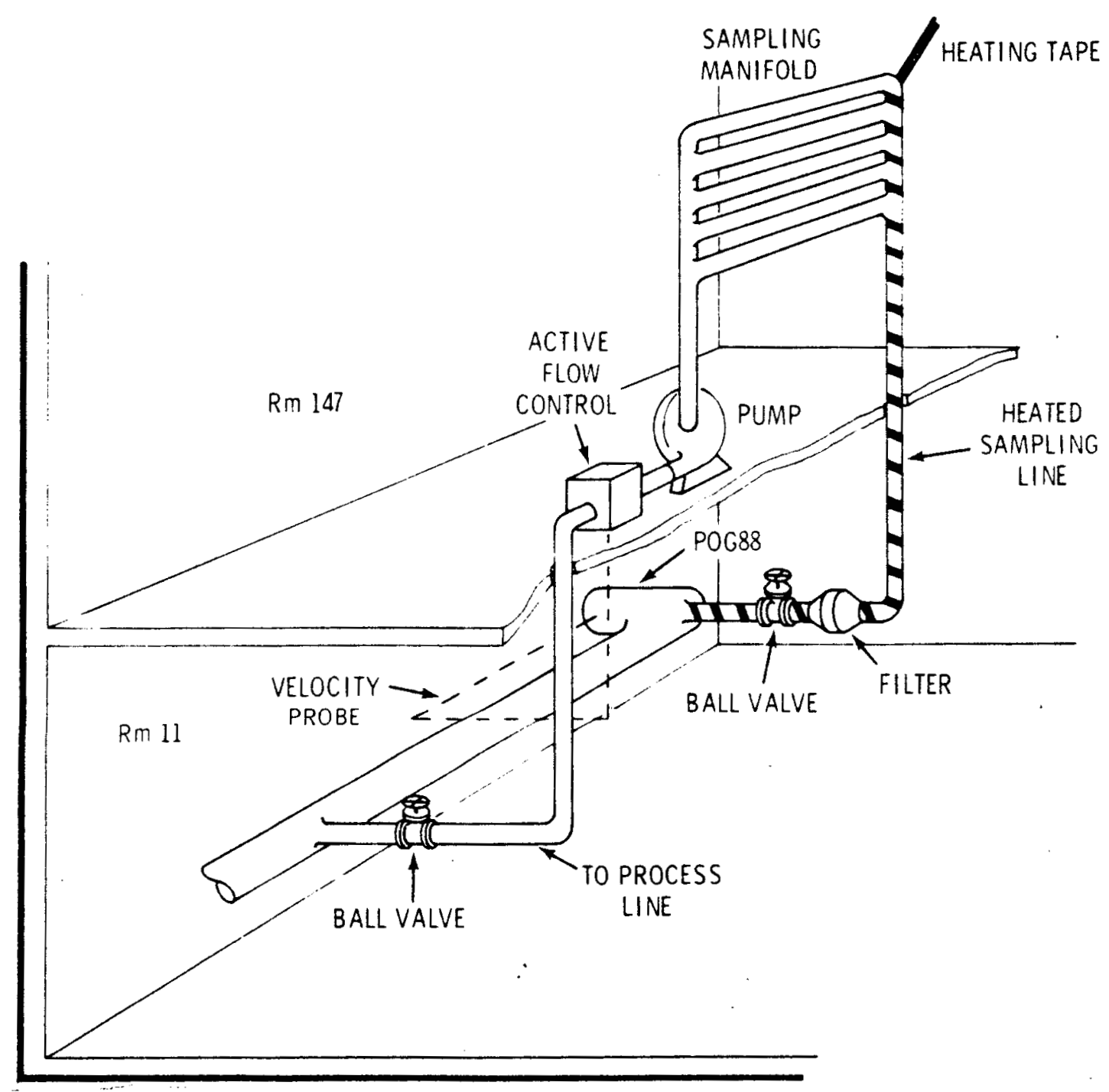

FIGURE 2. Process Line Sampling Site

tube, where it returned to the off-gas process 1 ine, POG-88, between absolute filter F104 and preheater E104. This closed loop sampling system is further illustrated in Figures 3 and 4.

In addition to the sampling site just described, an al ternative sampling location for gaseous radionuclides was established at the 324/325 main exhaust stack. This site was used as a backup to the main sampling station, located in Room 147, and allowed sampling materials incompatible with high 


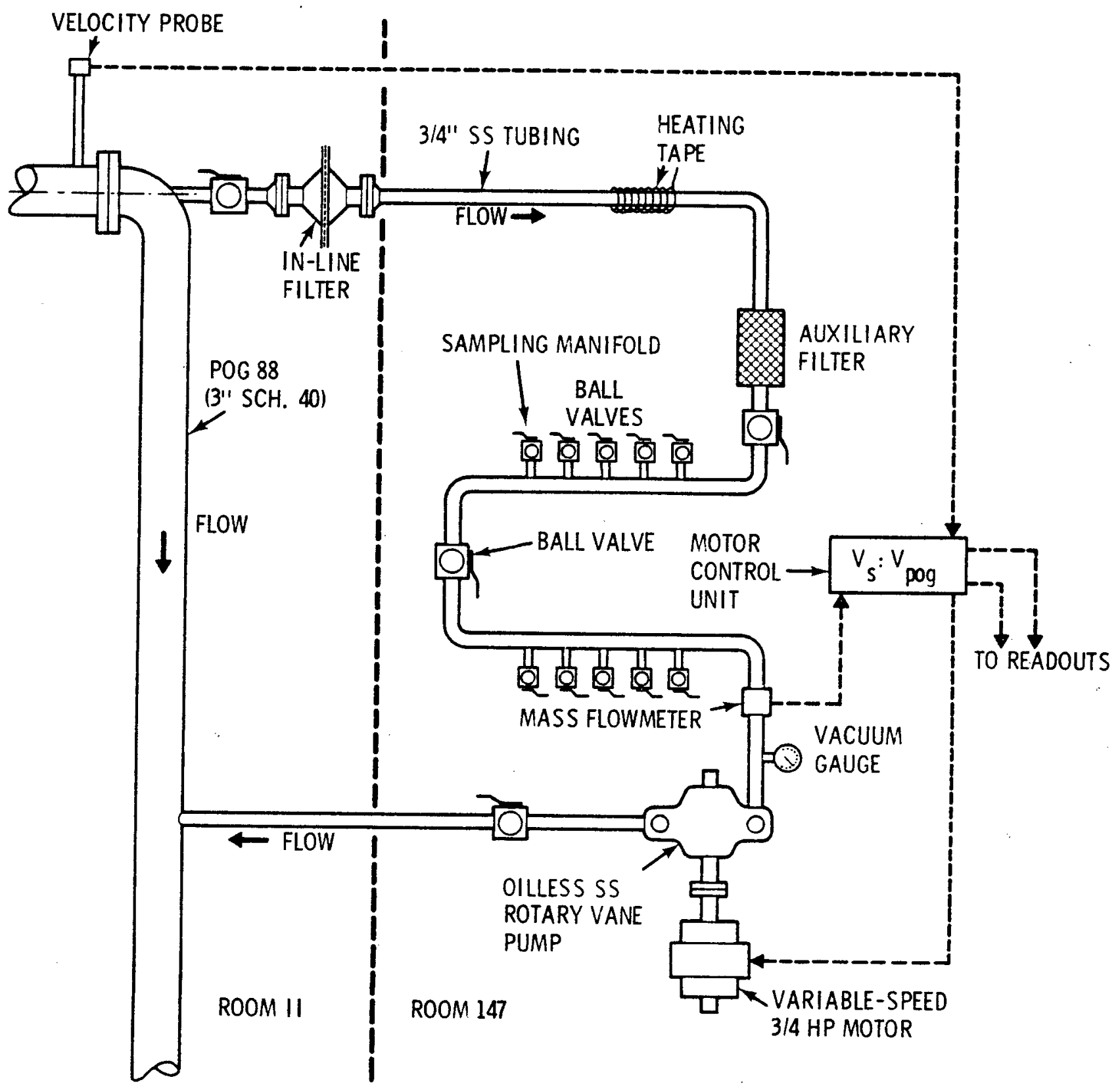

FIGURE 3. Detailed Schematic of the 324 Building Sampling System 


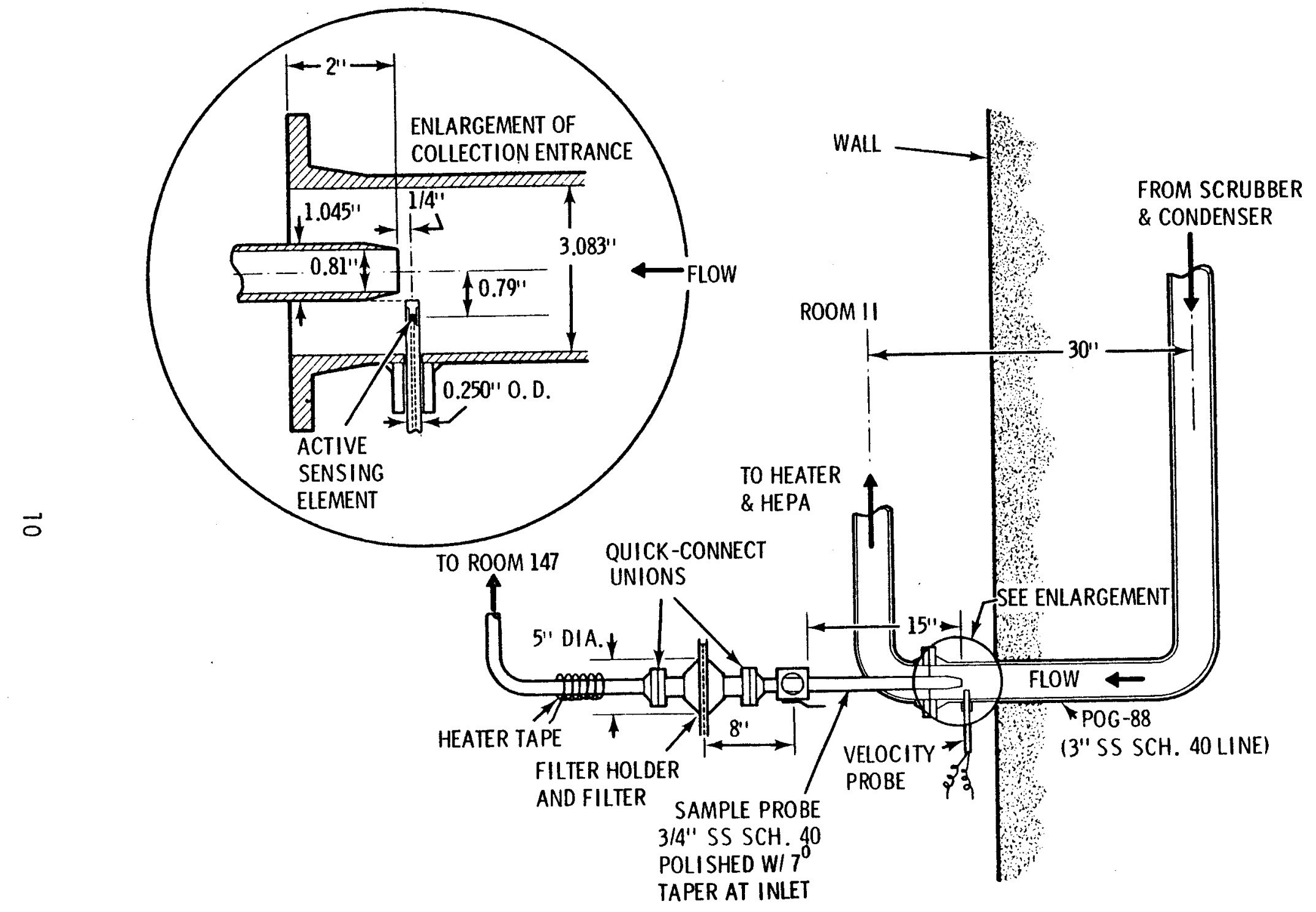

FIGURE 4. Detailed View of Sample Inlet 
NO $x$ concentration to be employed. Velocity probes located in the vitrification off-gas process line and in the main exhaust, which were calibrated in flow units using on-line mass spectrometer and helium dilution technique, permitted any effluent species measured at the stack to be related directly back to its emission rate in the off-gas process line and vice versa. The main disadvantage of the stack sampling location was that the vitrification process off-gas was diluted.by a factor of $10^{3}$ by building ventilation air, hood exhaust, and other hot-cell off-gas streams.

\section{SAMPLING NETWORK}

The sampling systems developed for this monitoring program were designed to characterize the concentrations of selected effluents (Table 1) escaping the process hot cell and, as such, are highly sensitive, integrating batchmode devices. In some cases, various chemical forms of a given isotope were selectively sampled for to gain as much information concerning the process as was possible. For example, various combinations of sorbing species and catalytic agents will permit selective sampling of three independent chemical forms of each of the following isotopes: ${ }^{3} \mathrm{H},{ }^{14} \mathrm{C}$ and ${ }^{129} \mathrm{I}$. These include: tritiated forms of water, hydrogen and organics; ${ }^{14} \mathrm{C}$-containing carbon monoxide, carbon dioxide, and organics; ${ }^{129}$ I-labeled iodine, hypoiodous acid, and organics.

Essentially all semivolatile isotopes listed in Table 1 possess acidic gaseous chemical forms and as such, were sampled by using a highly efficient caustic scrubber. In addition, on-line $\gamma$-ray spectrometry was employed to detect all gaseous r-emitting semivolatiles.

Particles were collected by a rather conventional means, but special attention was given to ensuring collection of as representative a sample as physically possible. Because erratic changes in process line flow rate were expected to occur, a truly active control network was designed so as to match the sampling rate to the instantaneous process off-gas velocity, thereby ensuring continuous isokinetic sampling conditions.

Although most sampling devices, as stated, were of the integrating batchmode variety requiring subsequent laboratory analysis, Ge(Li) gamma-ray 
detector systems were also employed as quasi-real time, general purpose, survey instruments analytically applicable to all gaseous forms of gammaemitting radionuclides. Each sampling system used is described in more detail in sections that follow.

${ }^{3} \mathrm{H}$ and ${ }^{14} \mathrm{C}$

Of the radioactive elements that can be expected to be volatilized during the calcination process, ${ }^{3} \mathrm{H}$ and ${ }^{14} \mathrm{C}$ form by far the greatest number of chemically different volatile species. Thus any sampling system designed to characterize tritium and ${ }^{14} \mathrm{C}$ in an off-gas stream has to address itself to the many chemical identities assumed by these isotopes. The sampling system developed for this program, to differentially trap all expected major forms of tritium and ${ }^{14} \mathrm{C}$ according to chemical class, is illustrated in Figure 5. The first trap in the series arrangement shown in Figure 5 consists of a highly efficient desiccator, silica gel, which selectively removes all tritiated forms of water (HTO, $T_{2} O$ and DTO). The second trap consists of a $\mathrm{CO}_{2}$ scrubber, Ascarite, ${ }^{\otimes}$ which collects all ${ }^{14} \mathrm{CO}_{2}$ present in the air stream. The sampled gas then passes through a third trap (HT) containing a platinum catalyst at room temperature and $3 A^{\circ}$ Molecular Sieve that catalytically oxidizes all hydrogen components of the gas stream $\left(H_{2}, H T, T_{2}, D T, D_{2}, H D, D T\right)$ and adsorbs the oxidized products in situ. $(2,3)$ A Hopcal ite catalyst is then used to oxidize the $\mathrm{CO}$ component of the gas stream to $\mathrm{CO}_{2}$; then the fourth trap, containing the $\mathrm{CO}_{2}$ scrubber, Ascarite, removes this source of ${ }^{14} \mathrm{C}$ from the sample gas stream. A platinum catalyst at $600^{\circ} \mathrm{C}(4)$ is subsequently used to completely oxidize all organic constituents in the sampling stream. The oxidation products-water and carbon dioxide--are separately trapped as previously described. But in this case they are representative of the tritium and ${ }^{14} \mathrm{C}$ contents of organic effluent present in the

Ascarite is a registered trademark of the Arthur H. Thomas Company, Philadelphia, PA.

- The $3 \mathrm{~A}$ is a registered trademark of Union Carbide Corporation's Linde Molecular Sieves, Long Beach, CA.

- Hopcalite is a registered trademark of MSA-Mine Safety Appliances Company, Pittsburgh, PA. 


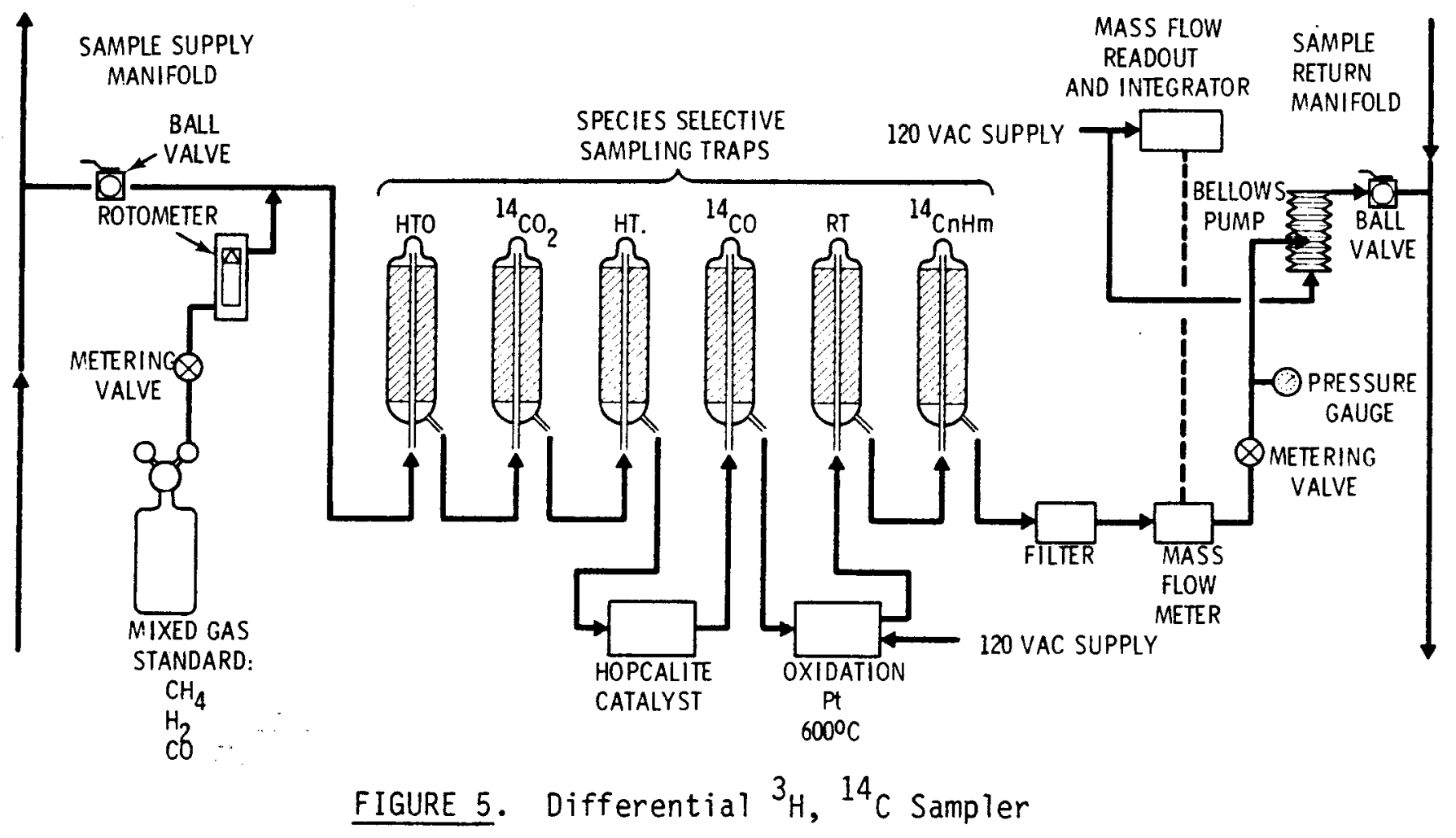

sampled gas. To ensure quantitative removal of trace gaseous components present in the process off-gas stream, a carrier gas containing "dead" $\mathrm{H}_{2}$, $\mathrm{CO}$ and $\mathrm{CH}_{4}$ was bled into the sampled gas stream before any contact with the species selective traps. Back-up traps also were employed with each speciesselective trap to establish collection efficiency.

129

Iodine was sampled both in the undiluted process off-gas stream and at the stack. At the primary sampling location, in Room 147 of the 324 Building, a packed column, counter-current flow caustic scrubber was used along with three heated beds of silver-exchanged Norton Zeolon $900^{\circ}$ to quantitatively remove all iodine from the sampled undiluted process off-gas. This sampling subsystem is illustrated in Figure 6 . The scrubber was operated continuously throughout

- Zeolon 900 is a registered trademark of the Norton Chemical Company, Akron, $\mathrm{OH}$. 


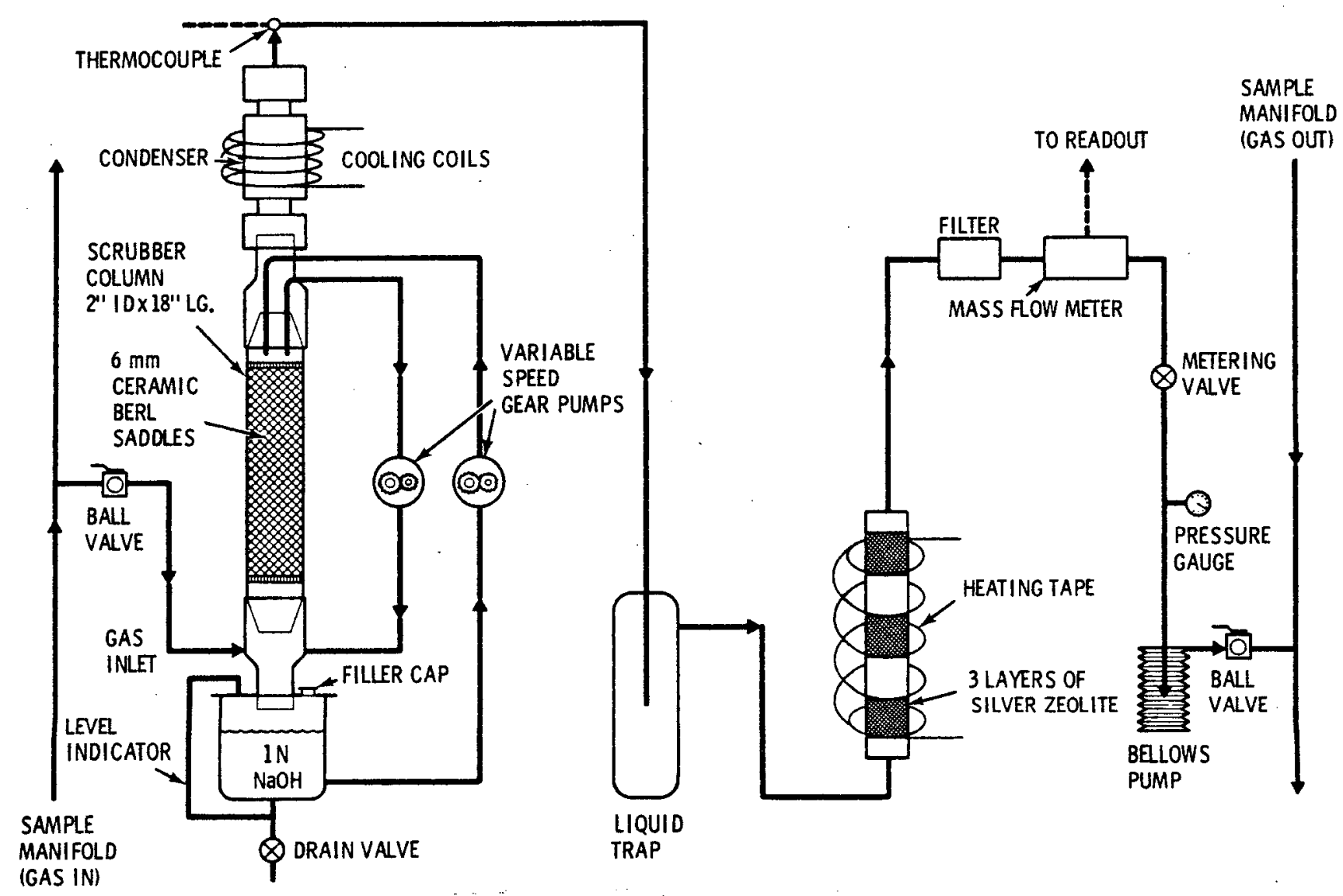

FIGURE 6. Caustic Scrubber Sampling System

the entire second vitrification campaign at a flow rate of $10 \mathrm{l} / \mathrm{min}$. A mass flow meter/integrator system measured the total volume of process off-gas stream sampled.

At the stack, species sampling for iodine was attempted. ${ }^{(5,6)}$ A three-

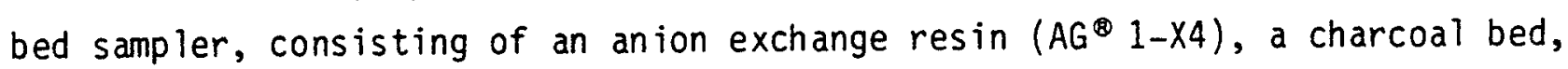
and silver-exchanged zeolite, was used to gain some idea of the species of iodine being exhausted to the atmosphere. All sampling beds were maintained at room temperature and were of sufficient thickness, at the sampled flow rate of $10 \mathrm{l} / \mathrm{min}$, to ensure maximum trapping efficiencies. (7) Again, flow and total sampled volume were measured with a mass flow/integrating totalizer system.

- AG is a registered trademark of the Bio-Rad Laboratories, Richmond, CA. 
$\stackrel{\text { NO }}{x}$

A commercial nitrogen oxide monitoring system manufactured by Monitoring Labs, Inc., was used at the stack monitoring location to determine nitrogen oxide concentrations. Both $\mathrm{NO}_{x}$ and $\mathrm{NO}$ were measured throughout the second vitrification campaign.

Semivolatiles

The semivolatile isotopes listed in Table 1 all possess acidic gaseous chemical forms allowing these species to be removed from the process off-gas by caustic scrubbing techniques. A highly efficient, packed column, countercurrent flow, $1 \mathrm{M} \mathrm{NaOH}$ scrubber system, shown in Figure 6 , was used to sample for these isotopes. Experimental scrubbing efficiences of greater than 95\% for both $\mathrm{CO}_{2}$ and $\mathrm{I}_{2}$ have been achieved with this system. Flow and total sampled volume were determined by a mass flow/integrating totalizer system. In addition, an on-line $\gamma$-ray spectrometric system continuously monitored the process off-gas stream for all $\gamma$-emitting semivolatiles.

\section{Particulates}

Particles were collected in a more or less conventional manner. However, special attention was devoted to ensuring collection of a truly representative sample. Sampling was done with a 3/4-in. Sch-40 SS, tapered and polished pipe located along the axis of the $3-i n$. process line, POG-88. The sampled gas and all entrained particles moved along this uniform diameter pipe directly to a commercially available filter of known collection efficiency. This filter was located as close as physically possible to the process line and along a common central axis defined by the collection tube and the process line itself, thereby ensuring a straight, short shot to the filter. Because erratic changes were expected to occur in the process line flow rate, a truly active control network was designed to match the sampling rate to the instantaneous process off-gas velocity, thereby ensuring continuous isokinetic sampling conditions.

Figures 3 and 4 illustrate the sampling system described above. Details of the various parallel sampling lines appear elsewhere in this report. 
Two Ge(Li) y-ray detectors were utilized in conjunction with high geometry gas cells to examine the filtered vitrification process off-gas. Pertinent typical specifications for this matched pair of detectors are listed in Table 2. These two spectroscopic systems were identical except that one included a ruthenium trap that protected one spectroscopy cell from possible contamination with ${ }^{106} \mathrm{Ru}$. The dual gaseous gamma-ray detection system is illustrated in Figure 7 . Since Room 147 was a radiation zone, each detector was housed in a lead cave with 4 in. of shielding on all sides.

Grab Samples

To guard against the unexpected, a grab sample capability was established as part of the sampling network. Three teflon-lined SS cylinders were used to collect filtered process off-gas at various times during the vitrification campaign. This sampling system is depicted in Figure 8 .

TABLE 2. Ge(Li) Detector Specifications, Resolution and Efficiency

\begin{tabular}{|c|c|c|c|c|}
\hline I sotope & ${ }^{57} \mathrm{Co}$ & ${ }^{137} \mathrm{Cs}$ & ${ }^{60} \mathrm{Co}$ & ${ }^{228}{ }_{T h}$ \\
\hline Energy, kev & 122 & 662 & 1332 & 2614 \\
\hline FWHM, keV & 0.74 & 1.30 & 1.80 & 2.66 \\
\hline FWTM, keV & 1.42 & 2.51 & 3.45 & 5.10 \\
\hline Peak/Compton & - & $38: 1$ & $27: 1$ & $15: 1$ \\
\hline Efficiency, $\%$ & $18^{(a)}$ & - & 4.5 & - \\
\hline
\end{tabular}

a. At end cap. 


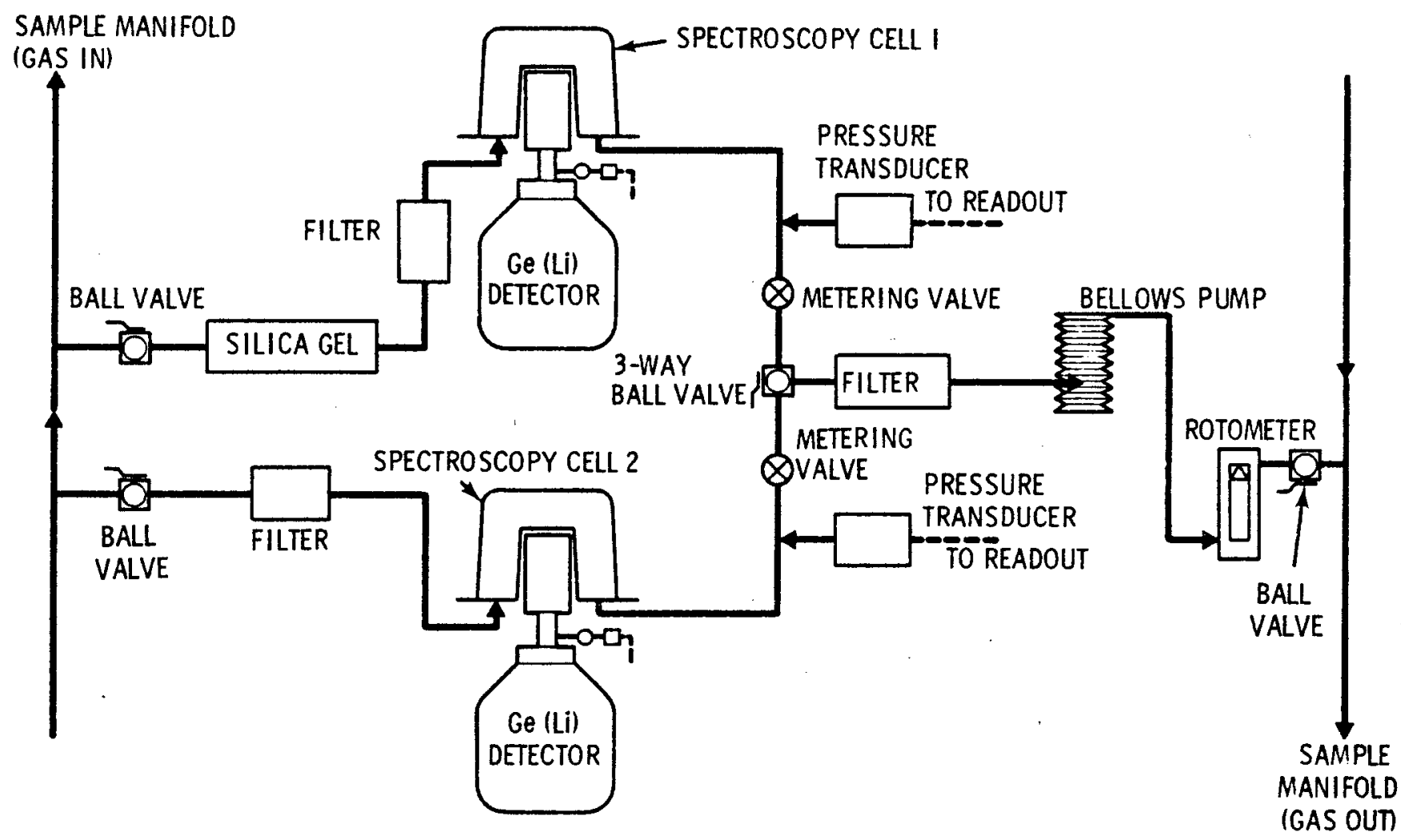

FIGURE 7. On-Line $r$-Analys is System

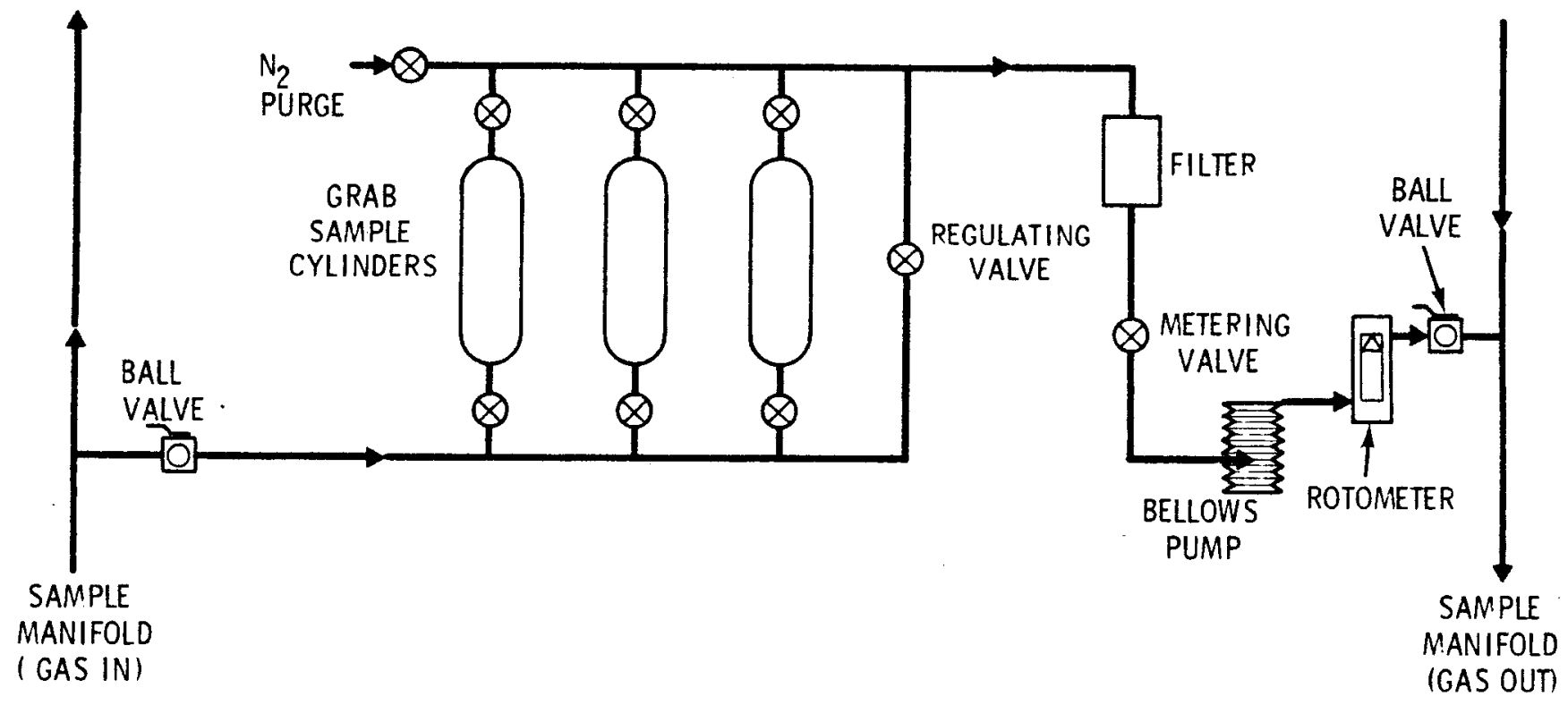

FIGURE 8. Grab Sample Apparatus 


\section{LABORATORY SAMPLE PREPARATION AND ANALYSIS}

Except for the on-line, quasi real-time $r$-ray analysis subsystem, most sampling devices used were of the integrating batch mode variety requiring subsequent laboratory analysis. This section describes the methods employed for sample preparation and analysis.

$\underline{3_{H}}$

The three sampled forms of tritium-tritiated water, hydrogen and organics--were collected in the chemical form of water on a desiccant--either silica gel or molecular sieve. The water was extracted from these desiccants by vacuum distillation at $530^{\circ} \mathrm{C}$. In the case of the hydrogen and organic tritium traps, where the quantity of collected water is sma11, dead water was used to push out the sample memory left on the desiccant. (2) This method allows the total sample to be extracted from the desiccating material.

After extraction of the water samples, aliquots were taken and mixed with a liquid scintillation solution, Insta-Gel, ${ }^{\oplus}$ and counted with liquid scintillator counter. This analytical system exhibited a total tritium counting efficiency of $13 \%$ and a background of $10 \mathrm{cpm}$.

${ }^{14} \mathrm{C}$

All forms of sampled ${ }^{14} \mathrm{C}$, carbon dioxide, carbon monoxide, and organics were collected in the chemical form of $\mathrm{CO}_{2}$, either on Ascarite or on molecular sieves. ${ }^{(8)}$ Chemically Ascarite is $\mathrm{NaOH}$ suspended on an asbestos substrate. The collected $\mathrm{CO}_{2}$ sample was extracted by dissolving it in water and precipitating the resultant $\mathrm{CO}_{3}=$ ion with $\mathrm{Ba}^{++}$.

In the case of molecular sieve adsorption of $\mathrm{CO}_{2}$, the sample $\left(\mathrm{CO}_{2}\right)$ was extracted from the sieve material by vacuum distillation at $530^{\circ} \mathrm{C}$. The 1 iberated $\mathrm{CO}_{2}$ was collected by a liquid nitrogen-cooled trap. After collection was completed, the frozen sample was connected to a closed-loop recirculation system containing a caustic bubbler. The sample was allowed to warm and was

(8) Insta-Gel is a registered trademark of Packard Instrument Company, Downers Grove, IL. 
continuously bubbled through the caustic solution until totally absorbed. The resultant $\mathrm{CO}_{3}=$ ion was then precipitated as $\mathrm{BaCO}_{3}$, as before.

The extracted samples of ${ }^{14} \mathrm{C}$ were counted by liquid scintillation techniques. In this method (9). a liquid scintillation compatible $\mathrm{CO}_{2}$ absorber,

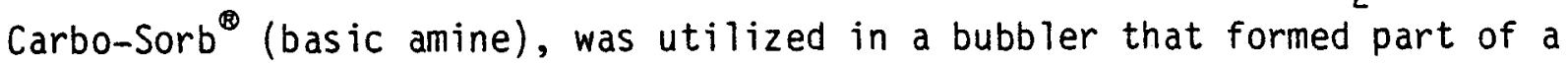
closed-loop recirculation system. The sample, in the form of $\mathrm{BaCO}_{3}$, was introduced into the closed system and acidified to convert the sample to $\mathrm{CO}_{2}$. The $\mathrm{CO}_{2}$ was continuously recycled through the Carbo-Sorb until absorption was complete. The absorbed sample was then mixed with a toluene-based scintillator, Permafluor II, and counted with a liquid scintillation detection system. This detector system possessed a ${ }^{14} \mathrm{C}$ counting efficiency of $80 \%$ and a background of 25 counts/min.

$129_{\text {I }}$

Iodine samples were collected on and in a variety of substrates, including resins, charcoals, silver-exchanged mordenites, and caustic solutions. The bas is of analysis for all these samples involved basically $r$-ray spectrometry. Resins, charcoals and silver-exchanged mordenites were counted in a fixed geometry between two opposed $\mathrm{Ge}(\mathrm{L} i)$ detectors operated in a summing mode. The $39.5 \mathrm{keV} \gamma$-ray served as a measure of the quantity of ${ }^{129}$ I present in these samples. Aliquots of the caustic solutions, used in the pack column scrubber, were counted in germanium well detectors. In all cases the samples were compared to reference materials obtained from the National Bureau of Standards that were prepared to resemble the samples as closely as possible.

In addition, the iodine in selected samples was extracted from the trapping substrates, loaded into ampoules and irradiated in a nuclear reactor. The neutron-activated samples were again counted utilizing $r$-ray spectrometry to establish total ${ }^{129}$ I contents in low-level samples.

\footnotetext{
- Carbo-Sorb and Permafluor are registered trademarks of Packard Instrument Company, Inc., Downers Grove, IL.
} 
$\stackrel{\text { NO }}{x}$

Nitrogen oxide measurements were made on a real-time basis at the stack monitoring site. The Monitor Labs' $N O-N_{x}$ detection system* employs the well established chemiluminescent reaction of nitric oxide, NO, and ozone to measure NO concentrations. This instrument, using a high-temperature thermodynamic converter, establishes $\mathrm{NO}_{x}$ concentrations by converting $\mathrm{NO}_{2}$ to $\mathrm{NO}$.

\section{SEMIVOLATILES}

The semivolatile elements were sampled for, using $r$-analys is of the process off-gas stream and a caustic scrubber. Gamma-ray spectrometry of scrubber solutions was utilized analytically to determine the presence of all r-emitting isotopes. However, ${ }^{79} \mathrm{Se}$ and ${ }^{99} \mathrm{Tc}$, because they are low-energy B-emitters, required chemical separation and low-level counting procedures. The chemical methods employed in these determinations are discussed below.

Technetium-99 was separated from the caustic scrubber solution by use of an anion exchange resin. The sample plus tracer was then eluted from the resin, purified, electrodeposited, and finally counted, utilizing a low-level $B^{-}$detector. Chemical yield was established by using a ${ }^{97 m_{T C}}$ spike.

Technetium-99 having been separated as described above, the scrubber solution plus carrier was acidified with $\mathrm{HCl}$. The oxyacid anion of selenium was then reduced to the metallic state by use of $\mathrm{SO}_{2}$. The elemental precipitate was purified and $B^{-}$counted as previously described. The quantitative nature of this chemical procedure was established using a ${ }^{75}$ Se spike; however, chemical yield of the actual sample was established gravimetrically.

\section{PARTICULATES}

The particulate analyses fall into two distinct categories: analysis of radionuclide or elemental composition and characterization of particle size. The radionuclide analyses were conducted primarily utilizing $r$ - and $x-r a y$ spectrometric techniques. The membrane filter was counted on a variety of

\footnotetext{
*This system is manufactured by Monitor Labs, Inc., San Diego, CA.
} 
$\gamma$-ray and $x$-ray detectors for qualitative and quantitative purposes. Quantitative results were obtained by mocking up standards to represent as closely as possible the sample being analyzed.

Particle size analysis was conducted utilizing scanning electron microscopy (SEM). Three sections of filter were cut and mounted on slides for SEM analysis. Thirty-eight photographs were made and processed for high-resolution quality prints on 1/2-thickness photographic paper (see Figure 9). The effective magnification of the prints was 20,000 . Size determinations were made using a Zeiss particle counter, where a spot size is adjusted to match a counted particle with respect to equivalent areas. The counts are recorded in grouped intervals. Particle diameters below $0.05 \mu \mathrm{m}$ were excluded by the limitations in resolution and the inconsistencies from one print to the next and thus established a cut-off point in the data. 


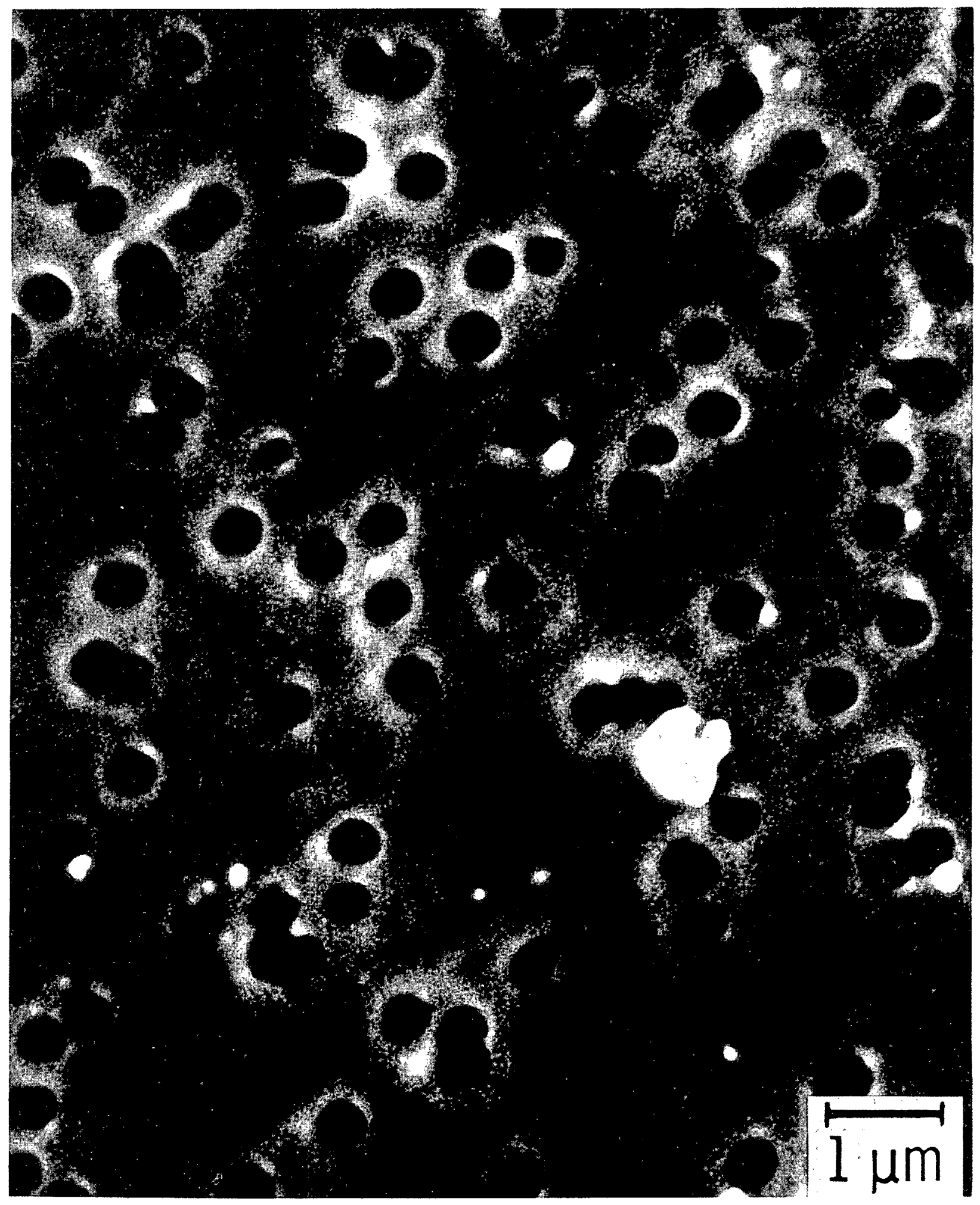

FIGURE 9. SEM-Generated Photographs of $0.4 \mu \mathrm{m}$ Nuclepore Filter Sample. (Because of the use of fluorescence, particles are seen here as light spots against dark filter background.) 


\section{RESULTS}

In this section the analytical results obtained for the various samples taken during the vitrification campaign are presented and their significance discussed.

$\underline{3}$

Three independent chemical forms of tritium-tritiated water, hydrogen and organics--were sampled for during the last vitrification campaign, with the following results.

\section{Tritiated Water}

Three samples were taken to determine the tritiated water content of the vitrification process off-gas. Two of these samples were obtained with the ${ }^{3} \mathrm{H}-{ }^{14} \mathrm{C}$ species sampler, and the other sample was taken with the caustic scrubber. The quantitative removal of this species of tritium was established, in the case of ${ }^{3} \mathrm{H}_{-}{ }^{14} \mathrm{C}$ sampler, by the analytical results obtained from the back-up traps employed. The quantitative nature of the scrubber, on the other hand, was ensured by the high rate of exchange expected for tritiated water and by the low, $1^{\circ} \mathrm{C}$, exit temperature of the condenser associated with the scrubber. The results obtained for these samples appear in Table 3.

\section{TABLE 3. Tritium Emissions}

\begin{tabular}{|c|c|c|c|c|}
\hline Chemical & & Concer & tion & \\
\hline Form & Sample Type & P0G-88 & Stack $(a)$ & Uncertainty, $\%$ \\
\hline HTO & Scrubber & $1.26 \mu \mathrm{Ci} / \mathrm{m}^{3}$ & $1.08 \mathrm{nCi} / \mathrm{m}^{3}$ & 5 \\
\hline HTO & C Sampler & $1.13 \mu \mathrm{Ci} / \mathrm{m}^{3}$ & $0.96 \mathrm{nCi} / \mathrm{m}^{3}$ & 5 \\
\hline HTO & ${ }^{3} \mathrm{H}-{ }^{14} \mathrm{C}$ Sampler & $1.23 \mu \mathrm{Ci} / \mathrm{m}^{3}$ & $1.05 \mathrm{nCi} / \mathrm{m}^{3}$ & 5 \\
\hline HT & ${ }^{3} \mathrm{H}-{ }^{14} \mathrm{C}$ Sampler & $<1 \mathrm{pCi} / \mathrm{m}^{3}$ & - & - \\
\hline HT & ${ }^{3} \mathrm{H}-{ }^{14} \mathrm{C}$ Sampler & $<1 \mathrm{pCi} / \mathrm{m}^{3}$ & - & - \\
\hline RT & ${ }^{3} \mathrm{H}-{ }^{14} \mathrm{C}$ Sampler & $2.9 \mathrm{nCi} / \mathrm{m}^{3}$ & $2.5 \mathrm{pCi} / \mathrm{m}^{3}$ & 5 \\
\hline RT & ${ }^{3} \mathrm{H}-{ }^{14} \mathrm{C}$ Sampler & $6.4 \mathrm{nCi} / \mathrm{m}^{3}$ & $5.5 \mathrm{pCi} / \mathrm{m}^{3}$ & 5 \\
\hline
\end{tabular}

a. Calculated from flow rate data. 
Tritiated Hydrogen

Two separate samples of the tritiated hydrogen component of the process off-gas stream were taken with the ${ }^{3} \mathrm{H}-{ }^{14} \mathrm{C}$ sampler. In both cases the results were below the detection limit of the liquid scintillation system employed. However, the very low yield of hydrogen carrier in the "HT trap" of the tritium sampler implied chemical poisoning of the room-temperature platinum catalyst by components in the process off-gas stream. If indeed this did occur, which cannot be proved conclusively, then the tritiated hydrogen component of the process off-gas stream, if any existed, would be hopelessly mixed with the organic sample. On the other hand, the process off-gas stream may have supported rapid oxidation of the carrier hydrogen, in which case the results are correct as they stand. Attempts to mock up the off-gas process conditions with $\mathrm{H}_{2}$ and $\mathrm{NO}_{2}$ added no support for the preoxidation notion; however, it did not disprove it since the composition of the off-gas stream is not completely known.

\section{Organic Tritium}

As in the case of tritiated hydrogen, two samples related to the tritiated organic component of the vitrification off-gas stream were taken sequentially. The analytical results obtained for these samples appear in Table 3. As was just discussed, this sample may be a composite containing tritium from both the organic and hydrogen components of the process off-gas stream.

${ }^{14} \mathrm{C}$

Three chemical forms of ${ }^{14} \mathrm{C}$ were sampled for during the vitrification of HLLW: ${ }^{14}$ C-containing carbon dioxide, carbon monoxide and organics. Two sets of samples of each species were taken sequentially during the final vitrification campaign. The analytical results obtained from these samples are tabulated in Table 4. The variability in these results, al though disconcerting, appears to be real. All laboratory results and procedures have been cross-checked, and duplicate analyses have been conducted. In addition, back-up traps have been fully analyzed to assess the possibility of breakthrough. The results of all these investigations reaffirm the data as listed in Table 4. 
TABLE 4. ${ }^{14} \mathrm{C}$ Emissions

\begin{tabular}{|c|c|c|c|c|c|}
\hline${ }^{14} \mathrm{C}$ Species & \multicolumn{4}{|c|}{ Concentration } & Uncertainty, \% \\
\hline \multirow{2}{*}{$\begin{array}{l}\text { Chemical } \\
\text { Form } \\
\end{array}$} & \multicolumn{2}{|c|}{ POG-88 } & \multicolumn{2}{|c|}{ Stack $(a)$} & \\
\hline & $\underline{\text { Samp }}$ & ample 2 & Samp & Sample 2 & Sample 1/Sample 2 \\
\hline & \multicolumn{2}{|c|}{$\left(n C i / m^{3}\right)$} & \multicolumn{2}{|c|}{$\left(p C i / m^{3}\right)$} & - \\
\hline $\mathrm{CO}_{2}$ & 70 & 180 & 59 & 150 & $5 / 5$ \\
\hline $\mathrm{CO}^{-}$ & 41 & 0.7 & 35 & 0.6 & $10 / 30$ \\
\hline $\mathrm{CnHm}$ & 31 & 20 & 26 & 17 & $5 / 5$ \\
\hline
\end{tabular}

a. Calculated from flow rate data.

$129^{1}$

Iodine samples were taken both at the primary sampling location in Room 147 and at the main exhaust stack. The scrubber and AgM back-up beds located in Room 147 measured the total iodine concentration in the process off-gas stream. The stack house monitor contained species-selective sorption beds of resin, charcoal, and silver zeolite in a series configuration. The resin bed was designed as a primary trap for molecular iodine. The charcoal bed was used to trap all other forms of iodine present. The AgZ bed acted as an absolute back-up for the two preceding sorption beds. The analytical results obtained from these samples are listed in Table 5. No specific sampling was conducted for HOI, if indeed such a species exists, since sampling methods for this chemical form of iodine have not been well developed or adequately tested.

NO $x$

Nitrogen oxides were measured at the stack sampling location with a commercially available $\mathrm{NO}^{-\mathrm{NO}} \mathrm{x}$ monitor. Previtrification background levels for $\mathrm{NO}$ and $\mathrm{NO}_{\mathrm{x}}$ were, nominally, $0.3 \mathrm{ppm}$ and $0.5 \mathrm{ppm}$, respectively. During active vitrification the main stack exhaust exhibited a tenfold increase in nitrogen oxide emissions. Average values for $\mathrm{NO}$ and $\mathrm{NO}_{\mathrm{x}}$ measured at the stack during this period were: $3 \mathrm{ppm}$ and $5 \mathrm{ppm}$, respectively. The peak value observed for 
TABLE 5. Iodine Emissions

\begin{tabular}{|c|c|c|c|c|c|c|}
\hline \multirow{2}{*}{$\begin{array}{l}\text { Chemical } \\
\text { Form }\end{array}$} & \multirow{2}{*}{$\begin{array}{l}\text { Sampling } \\
\text { Site } \\
\end{array}$} & \multirow{2}{*}{$\begin{array}{c}\text { Samp ler } \\
\text { Type }\end{array}$} & \multirow[b]{2}{*}{ Concentration } & \multicolumn{2}{|c|}{ Total } & \multirow{2}{*}{$\begin{array}{c}\text { Error, } \\
\% \\
\end{array}$} \\
\hline & & & & POG-88 & Stack & \\
\hline Al1 & Room 147 & Scrubber/AgZ & $1.0 \mathrm{nCi} / \mathrm{m}^{3}$ & $1.0 \mathrm{nCi} / \mathrm{m}^{3}$ & $\left(0.86 \mathrm{pCi} / \mathrm{m}^{3}\right)^{(\mathrm{a})}$ & 5 \\
\hline & Stack & Resin & $0.4 \mathrm{pCi} / \mathrm{m}^{3}$ & & & \\
\hline$A 1^{2}(b)$ & Stack & Charcoal & $0.6 \mathrm{pCi} / \mathrm{m}^{3}$ & $\left(1.2 \mathrm{nCi} / \mathrm{m}^{3}\right)^{(\mathrm{a})}$ & $1 \mathrm{pCi} / \mathrm{m}^{3}$ & 25 \\
\hline$A 11^{(b)}$ & Stack & $\mathrm{AgZ}$ & $<50 \mathrm{fCi} / \mathrm{m}^{3}$ & & & \\
\hline
\end{tabular}

a. Calculated from flow rate data.

b. All forms except $\mathrm{I}_{2}$.

${ }^{\mathrm{NO}} \mathrm{x}$ during vitrification was $8 \mathrm{ppm}$. With the completion of spray calcining, the levels for $\mathrm{NO}$ and $\mathrm{NO} \mathrm{X}_{\mathrm{x}}$ dropped to $0.5 \mathrm{ppm}$ and $1.5 \mathrm{ppm}$, respectively.

\section{SEMIVOLATILES}

Direct $\gamma$-ray spectrometry of the process off-gas stream and of the scrubber solutions was used to determine the concentration of gaseous $\gamma$-ray-emitting semivolatiles. All r-emitting semivolatile isotopes listed in Table 1 were below the detection limit of the analytical systems employed. However, an average total $\gamma$-ray activity per unit volume of the process off-gas stream was estimated from the data generated. These results are summarized in Table 6.

TABLE 6. Semivolatile Emissions

\begin{tabular}{|c|c|c|c|}
\hline Isotope & Detection Method & Concentration & Error, \% \\
\hline & & (POG-88) & \\
\hline${ }^{79} \mathrm{Se}$ & & $<20 \mathrm{fCi} / \mathrm{m}^{3}$ & \\
\hline${ }^{99} \mathrm{TC}$ & $B^{-}$Counting & $1.6 \mathrm{pCi} / \mathrm{m}^{3}$ & 8 \\
\hline${ }^{106} \mathrm{Ru}$ & & $<200 \mathrm{nCi} / \mathrm{m}^{3}$ & \\
\hline${ }^{125} \mathrm{Sb}$ & & $<50 \mathrm{nCi} / \mathrm{m}^{3}$ & \\
\hline${ }^{126} \mathrm{Sb}$ & & $<3 \mathrm{nCi} / \mathrm{m}^{3}$ & \\
\hline $125 \mathrm{~m}_{\mathrm{Te}}$ & $\gamma$ Analys is & $<0.1 \mathrm{nCi} / \mathrm{m}^{3}$ & \\
\hline${ }^{134} \mathrm{Cs}$ & & $<6 \mathrm{nCi} / \mathrm{m}^{3}$ & \\
\hline${ }^{137} \mathrm{Cs}$ & & $<100 \mathrm{nCi} / \mathrm{m}^{3}$ & \\
\hline Al1 & & $10^{5} \frac{\mathrm{r} / \mathrm{sec}}{\mathrm{m}^{3}}$ & 50 \\
\hline
\end{tabular}


The non $\gamma$-emitting semivolatile isotopes were chemically separated from the caustic scrubber solution and analyzed using low-level $\beta^{-}$counting techniques. The results of these analyses also appear in Table 6 . No attempt was made to measure ${ }^{135} \mathrm{Cs}$ since ${ }^{134} \mathrm{Cs}$ and ${ }^{137} \mathrm{Cs}$ served as excellent measures of the degree of process-induced volatility for all cesium isotopes.

\section{PARTICULATES}

Particulates were isokinetically collected utilizing a $0.4 \mu \mathrm{m}$ Nuclepore, ${ }^{\otimes}$ polycarbonate, membrane filter. This particulate sample was analyzed for both radionuclide content and size distribution. The radionuclide analysis was conducted utilizing $\gamma$ - and $x$-ray spectrometric techniques. The results of this analysis are summarized in Table 7. Comparison of the results appearing in Table 7 with calculated isotopic ratios expected in the vitrification feed indicates preferential volatilization of both ${ }^{106} \mathrm{Ru}$ and ${ }^{125 \mathrm{~m}} \mathrm{Te}$.

Particle size analysis was accomplished utilizing scanning electron microscopic techniques. Thirty-eight SEM-generated pictures $\left(2 \times 10^{4} \mathrm{X}\right.$ magnification) were evaluated with a Zeiss particle size analyzer. The resultant normalized histogram of that data appears in Figure 10. This size frequency distribution was analyzed empirically and by fitting the data to a log normal distribution. The results of this analysis are summarized in Table 8.

\section{TABLE 7. Radionuclide Content of Particulate Matter}

\begin{tabular}{|c|c|c|}
\hline I sotope & $\begin{array}{c}\text { Concentration, } \\
\mathrm{nCi} / \mathrm{m}^{3}\end{array}$ & $\begin{array}{c}\text { Error, } \\
6\end{array}$ \\
\hline${ }^{106} \mathrm{Ru}$ & 44. & 10 \\
\hline${ }^{125} \mathrm{Sb}$ & 0.52 & 10 \\
\hline $125 \mathrm{~m}_{\mathrm{Te}}$ & 1.7 & 15 \\
\hline${ }^{134} \mathrm{Cs}$ & 7.8 & 10 \\
\hline${ }^{137} \mathrm{Cs}$ & 52. & 10 \\
\hline${ }^{144} \mathrm{Ce}$ & 0.82 & 10 \\
\hline${ }^{154} \mathrm{Eu}$ & 0.28 & 30 \\
\hline${ }^{155} \mathrm{Eu}$ & 0.18 & 15 \\
\hline${ }^{241} \mathrm{Am}$ & 0.19 & 20 \\
\hline
\end{tabular}

Nuclepore is a registered trademark of Nuclepore Corporation, Pleasanton, CA. 


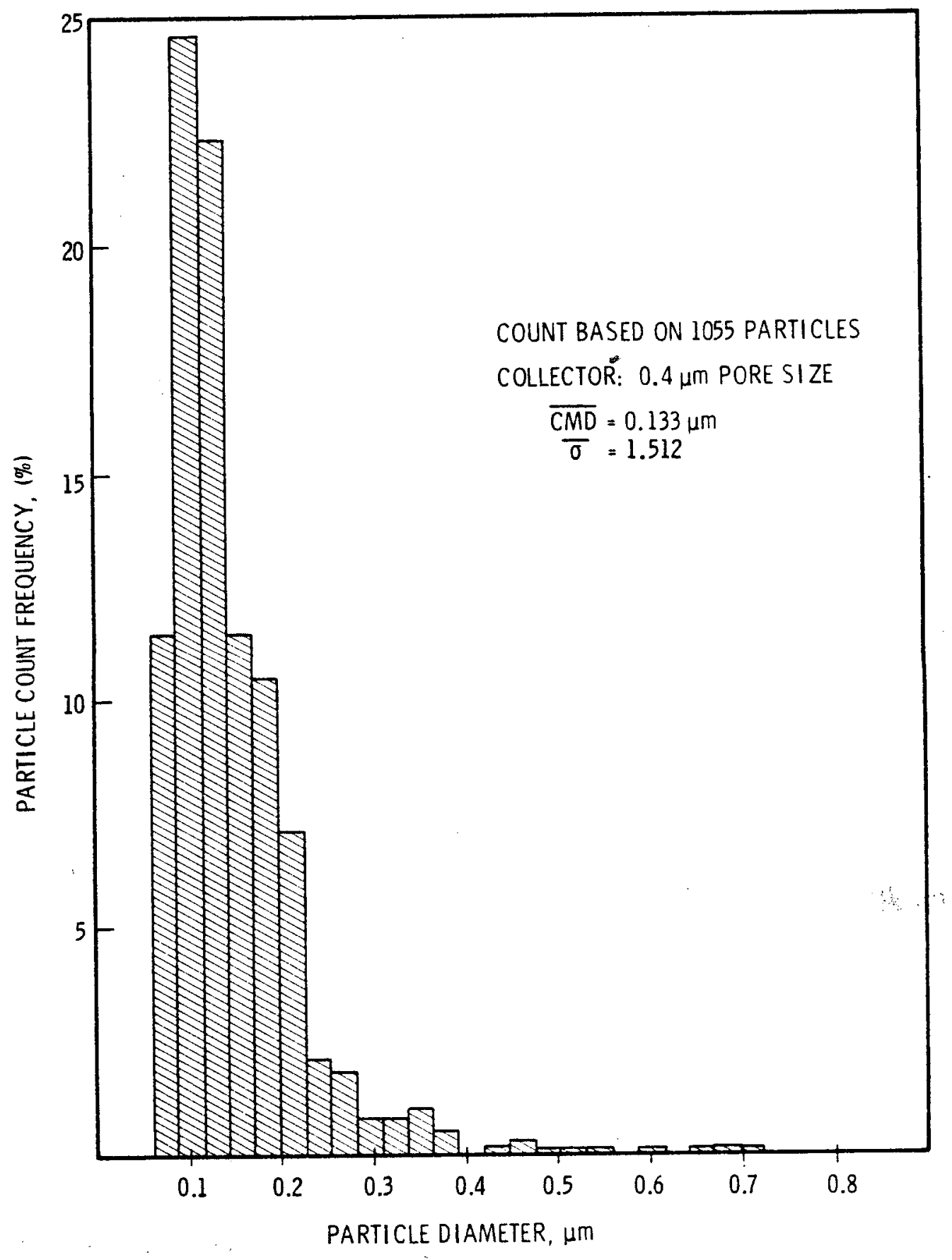

FIGURE 10. Histogram of Observed Count Frequency Versus Particle size Interval 
TABLE 8. Particulate Size Distribution Analys is

\begin{tabular}{|c|c|c|}
\hline Parameter (a) & Empirical & Log Normal \\
\hline Geometric mean diameter & $0.13 \mu \mathrm{m}$ & $0.10 \mu \mathrm{m}$ \\
\hline Geometric standard, deviation & 1.51 & 2.01 \\
\hline Correlation coefficient & - & 0.975 \\
\hline Mass mean diameter & - & $0.55 \mu \mathrm{m}$ \\
\hline Particle concentration & $168 / \mathrm{cm}^{3}$ & - \\
\hline Particle mass concentration (b) & $84.7 \mathrm{pg} / \mathrm{cm}^{3}$ & - \\
\hline
\end{tabular}

\footnotetext{
a. All parameters relate to undiluted process off-gas before

b. Assumed calcine density $-3 \mathrm{~g} / \mathrm{cm}^{3}$.
}

The fit of the data to a log normal distribution is illustrated in Figure 11. Since particles generated by the vitrification process must trave a tortuous route through sintered filters, evaporators, condensers, heaters, and scrubbers before reaching the sampling point, a good fit to the data would be fortuitous. However, the analytical description of this distribution provides a convenient parametric means for handling and evaluating the data.

The total efficiency of the Nuclepore filter employed as related to particle size was calculated using standard models and experimental data. Figure 12 summarizes the results of this efficiency calculation. Values for the total efficiency appearing in this figure serve only as a measure of confidence for the particle count at a specific size.

\section{$\underline{\text { DISCUSSION }}$}

Because of this program's limited scope, the authors have not attempted to interpret the analytical results in terms of environmental issues. The results of this study can, however, serve as a basis for evaluating the environmental implications associated with future waste solidification facilities. Although the analytical findings of this study are highly specific to NWVP, the emission characteristics of alternative off-gas processing systems may be appraised by comparing the efficiencies of their individual process line components with those exhibited by the NWVP analogues. 


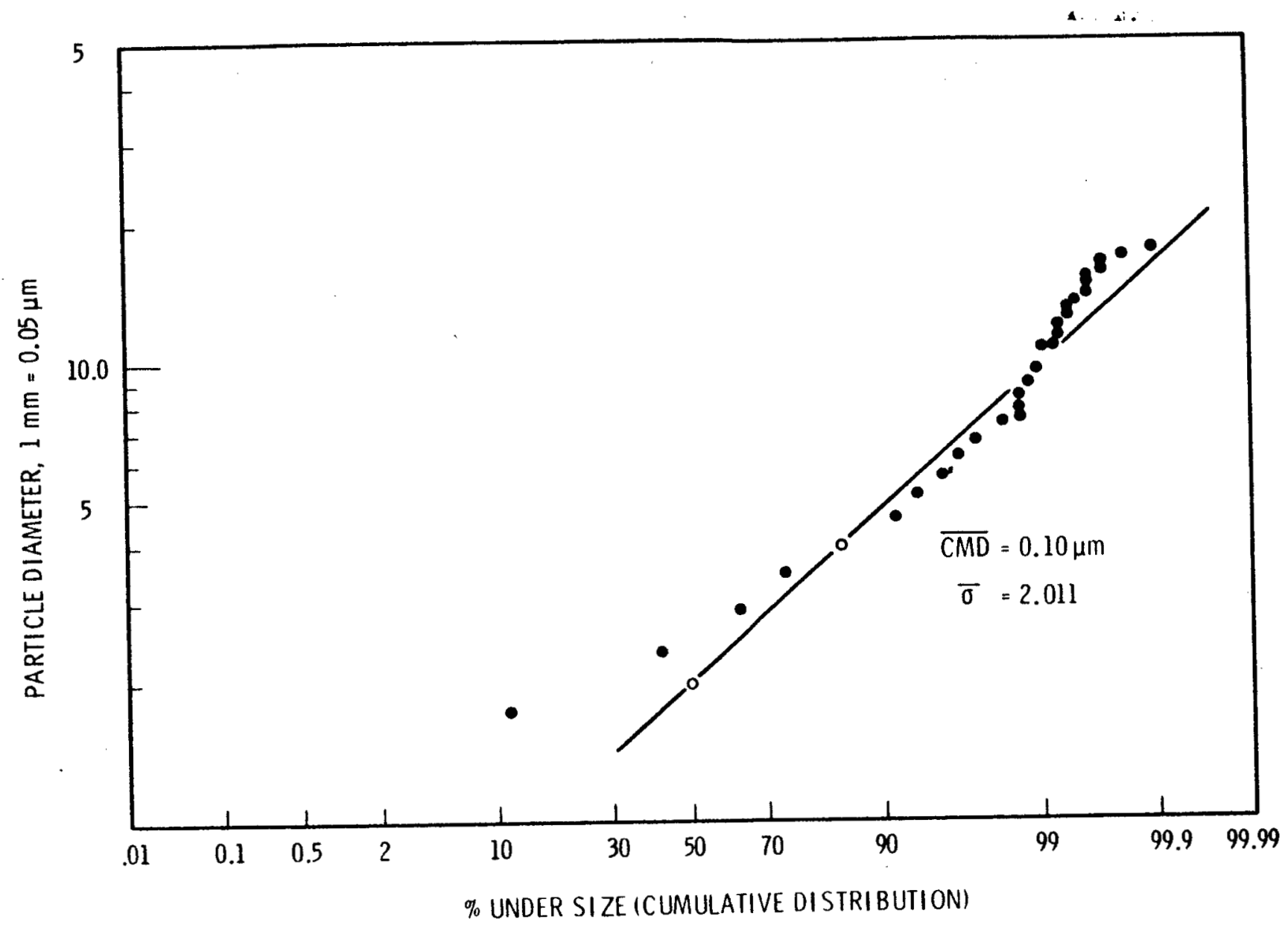

FIGURE 11. Log Normal Fit to Empirical Particle Distribution Data 


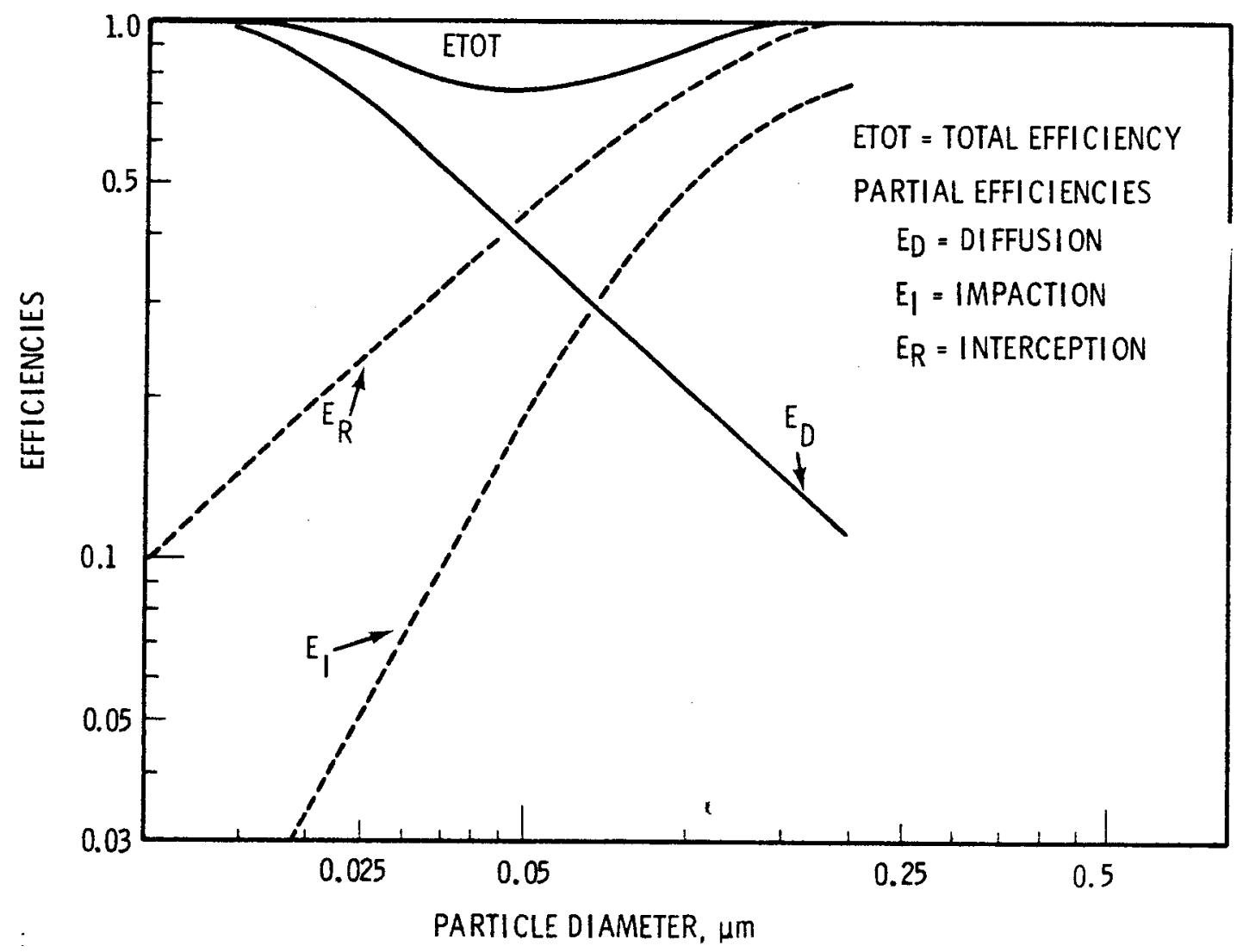

FIGURE 12. Semi-Empirical Particle Collection Efficiencies for a $0.4 \mu \mathrm{m}$ Nuclepore Membrane Filter 


\section{REFERENCES}

1. E. S. Wheelwright, W. J. Bjork lund, L. M. Browne, G. H. Bryan, L. K. Holton, E. R. Irish and D. H. Siemens, Technical Summary: Nuclear Waste Vitrification Project, PNL-3038, Pacific Northwest Laboratory, Richland, WA, 1979.

2. H. G. Ostlund, A Rapid Field Sampling System for Tritium in Atmospheric Hydrogen, AEC TID-25345, 1970.

3. H. G. Ostlund and A. S. Mason, "Atmospheric HT and HTO, "Tellus 26:1-2, 91-102 (1974).

4. W. R. Griffin, A. Cochran and A. A. Bertuccio, "A Sampler for Non-Aqueous Tritium Gases," Tritium Symposium, Las Vegas, NV, September 1971.

5. F. P. Brauer, R. W. Goles, J. H. Kaye and H. G. Rieck, Jr., "Sampling and Measurement of Long-Lived Radionuclides in Environmental Samples," BNWL-SA-6363. Proceedings of 4th Joint Conference on Sensing of Environmental Pollutants, New Or leans, LA, p. 330, November 6-11, 1977.

6. F. P. Brauer, H. G. Rieck and R. L. Hooper, "Particulate and Gaseous Atmospheric Iodine Concentrations." BNWL-SA-4732, in Physical Behaviour of Radioactive Contaminants in the Atmosphere, IAEA SM-181/6, International Atomic Energy Agency, Vienna, pp. 351-355, 1974.

7. T. R. Thomas, B. A. Staples, L. P. Murphy and J. T. Nichols, Airborne Elemental Iodine Loading Capacities of Metal Zeolites and a Method for Recycling Silver Zeolite. ICP-1119, Allied Chemical Corp., Idaho National Engineering Laboratories, Idaho Falls, ID, 1977.

8. G. J. Fergusson, "High-Volume Sampler for Atmospheric Carbon Dioxide." Rev. of Sci. Inst. 34:(4)403 (1963).

9. D. W. Hayes and K. W. MacMurdo, "Carbon-14 Production by the Nuclear Industry." Health Phys. 32:215 (1977).

10. J. Pich, "Impaction of Aerosol Particles in the Neighbourhood of a Circular Hole." Collect. Czech. Chem. Comm. 29:2223 (1964).

11. P. Gormley and M. Kennedy, "Diffus ion from a Stream Flowing Through a Cylindrical Tube." Proc. Roy. Irish Acad. A 52:163 (1949).

12. S. Twomey, "Equation for the Decay by Diffusion of Particles in an Aerosol Flowing Through Circular and Rectangular Channels." Bull. Observ. Puy Oome A 10:173 (1962). 
13. G. L. Natanson, Dok 1. Akad. Nauk USSR 112:100 (1957).

14. K. R. Spurnỳ and G. Madelaine, "Analytical Methods for Determination of Aerosols by Means of Membrane Ultrafilters. XIX. Efficiency of Measurement of Nuclear Pore Filters by Means of Latex Aerosols." Collect. Czech. Chem. Comm. 36:2857 (1971). 